\title{
Zmienność rytmu serca w ujęciu praktycznym - doceniany czy zapomniany parametr oceny holterowskiej?
}

\author{
Heart rate variability in practical term \\ - appreciated or forgotten parameter of Holter ECG monitoring?
}

\author{
Beata Przybysz-Zdunek, Renata Główczyńska \\ I Katedra i Klinika Kardiologii Warszawskiego Uniwersytetu Medycznego
}

\section{Streszczenie}

Zmienność rytmu serca (HRV) jest parametrem do oceny oscylacji w przerwach między uderzeniami serca odzwierciedlonej w odstępach RR zapisu elektrokardiograficznego. Obniżoną HRV uważa się za nieinwazyjny marker dysfunkcji układu autonomicznego, który może być czynnikiem predykcyjnym wielu chorób układu sercowo-naczyniowego prowadzących do zwiększonego ryzyka nagłego zgonu sercowego.

Słowa kluczowe: zmienność rytmu serca, badanie EKG metodą Holtera, czynnik rokowniczy

Folia Cardiologica 2017; 12, 6: 617-624

\section{Wstęp}

Choroby układu sercowo-naczyniowego, mimo dokonującego się ciagle postępu w medycynie i metodach terapeutycznych współczesnej kardiologii, nadal pozostają jedną z głównych przyczyn zgonów w krajach rozwiniętych [1]. Wobec powyższego identyfikacja osób zagrożonych najwyższym ryzykiem zgonu, w tym nagłego zgonu sercowego pozostaje ważnym i niezmiernie aktualnym zagadnieniem. Obok zastosowania powszechnie uznanych metod, jak na przykład ocena echokardiograficzna czynności skurczowej lewej komory, na przestrzeni ostatnich kilkunastu lat obserwowaliśmy rozwój i rozbudowę elementów oceny rytmu jako kolejnego filaru diagnostyki nieinwazyjnej. Jednym z nich stała się zmienność rytmu serca (HRV, heart rate variability) [2].

\section{Zmienność rytmu serca}

\section{Definicja}

Historycznie jednym z wyznaczników HRV była niemiarowość oddechowa, oceniana na podstawie spoczynkowego zapisu elektrokardiograficznego (EKG) rozszerzonego o rejestrację na szczycie wdechu i wydechu. Już w 1963 roku Hon i Lee [3] wykazali, że analiza HRV u płodu może być czynnikiem prognostycznym zagrożenia nagłym zgonem. Zmienność rytmu zatokowego dostarcza informacji o różnicach w długości interwałów RR. Różnice te są związane ze zdolnością adaptacji do zewnętrznych bodźców i stanowią informację o funkcjonowaniu autonomicznego systemu nerwowego. U osób zdrowych ciągłe, wzajemne oddziaływanie jego współczulnej i przywspółczulnej składowej prowadzi do zmian w średniej częstości rytmu serca [4]. Zmienność rytmu serca jest generowana przez aktywność węzła zatokowo-przedsionkowego i odzwierciedla działanie przede wszystkim przywspółczulnej części autonomicznego układu nerwowego [5].

\section{Metodologia}

Oceny HRV najczęściej dokonuje się za pomocą analizy czasowej lub częstotliwościowej. Uzupełnieniem są analiza czasowo-częstotliwościowa, inaczej falkowa, oraz analiza dynamiki nieliniowej. Analiza czasowa obejmuje metody statystyczne oraz metody geometryczne.

Adres do korespondencji: dr n. med. Renata Główczyńska, I Katedra i Klinika Kardiologii, Warszawski Uniwersytet Medyczny, Centralny Szpital Kliniczny, ul. Banacha 1a, 02-097 Warszawa, e-mail: renata.glowczynska@wum.edu.pl 


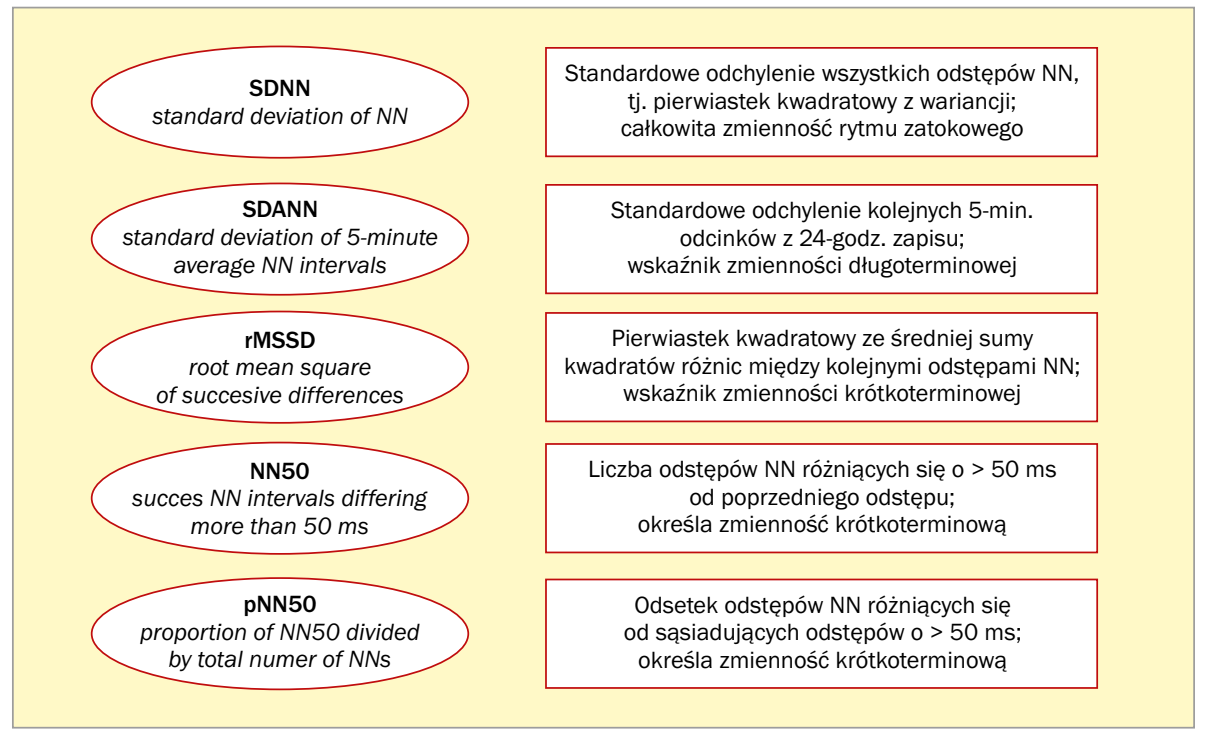

Rycina 1. Wyjaśnienia skrótów i opisy parametrów wykorzystywanych w analizie czasowej zmienności rytmu serca (opracowano na podstawie [6])

Metody statystyczne są stosunkowo proste obliczeniowo i zrozumiałe, natomiast ich wadą jest dość duża czułość na artefakty i pobudzenia dodatkowe, które trzeba wyeliminować z analizy. Zaleca się wykorzystanie fragmentu z odstępami RR (tachogramu) o częstotliwości próbkowania nie niższej niż $500 \mathrm{~Hz}$. Zweryfikowane odstępy RR są określane w analizie jako odstępy NN (ang. normal-to-normal) i są poddawane dalszej analizie [6]. W rycinie 1 podano wyjaśnienia skrótów i opisy najczęściej używanych parametrów. W tabeli 1 przedstawiono zakresy norm dla poszczególnych parametrów. W praktyce klinicznej najczęściej wykorzystuje się parametr SDNN, który jest miarą zmienności wszystkich odstępów NN w analizowanym okresie. Należy jednak pamiętać, że zmienność wolnego rytmu jest zwykle większa niż zmienność rytmu szybkiego, w związku z czym parametr SDNN wyliczany z godzin nocnych ma większą wartość niż wyliczony z godzin aktywności dziennej [8]. Według obecnych zaleceń European Society of Cardiology (ESC) analiza czasowa powinna być stosowana dla długotrwałych rejestracji EKG (najczęściej 24 h) [6]. Wskaźniki rMSSD, NN50 oraz pNN50 zależą od różnic między kolejnymi odstępami NN i odzwierciedlają przede wszystkim aktywność układu przywspółczulnego. Wśród nich w praktyce klinicznej bywa preferowany rMSSD - ze względu na lepsze właściwości statystyczne [9].

Niewątpliwą zaletą metod geometrycznych jest duża niezależność od jakości zapisu oraz od dodatkowych pobudzeń, o ile nie są one zbyt liczne. Konieczne są jednak długie, najlepiej 24-godzinne, okresy rejestracji. $Z$ wykorzystaniem metod geometrycznych prezentowany jest rozkład następujących po sobie odstępów RR i różnice w ich długościach [10]. Graficzne przedstawienie zależności między odstępami RR określa się jako rozkład
Tabela 1. Normy poszczególnych parametrów zmienności rytmu serca (zmodyfikowano na podstawie [7])

$\begin{array}{lc}\text { Zmienna } & \text { Zakres normy [ms] } \\ \text { Średni odstęp RR } & >750 \\ \text { SDNN } & 141 \pm 39 \\ \text { SDANN } & 127 \pm 35 \\ \text { rMSSD } & 27 \pm 12\end{array}$

Lorenza. Innym sposobem prezentacji jest histogram, który przedstawia gęstość dystrybucji, czyli rozkład odstępów RR o konkretnej długości w przedziałach czasowych (ryc. 2). Podaje się następujące parametry:

- wskaźnik trójkątny HRV $\left(\mathrm{HRV}_{\mathrm{i}}\right.$, heart rate variability triangular index) - całkę z funkcji gęstości. Aby obliczyć $H_{R V}$, należy liczbę wszystkich odstępów NN podzielić przez liczbę długości odstępów NN najczęściej występujących w histogramie (tj. maksimum funkcji gęstości rozkładu);

- interpolację trójkątną histogramu odstępów NN (wyrażaną $\mathrm{w}$ [ms]; TINN, triangular interpolation of NN interval histogram) - obliczana jako długość podstawy trójkąta aproksymującego rozkład odstępów NN na osi czasu (trójkąt ten wyznacza się tzw. metodą najmniejszych kwadratów) (ryc. 3).

Sposób obliczania HRV ${ }_{i}$ oraz TINN pozwala na eliminację artefaktów, które lokalizują się poza trójkątem. Oba te parametry są wyznacznikami długookresowej zmienności rytmu zatokowego i w znacznym stopniu korelują z całkowitą HRV [12].

Analiza częstotliwościowa (widmowa, spektralna) została wprowadzona przez Akselroda i wsp. [13]. Jej podsta- 


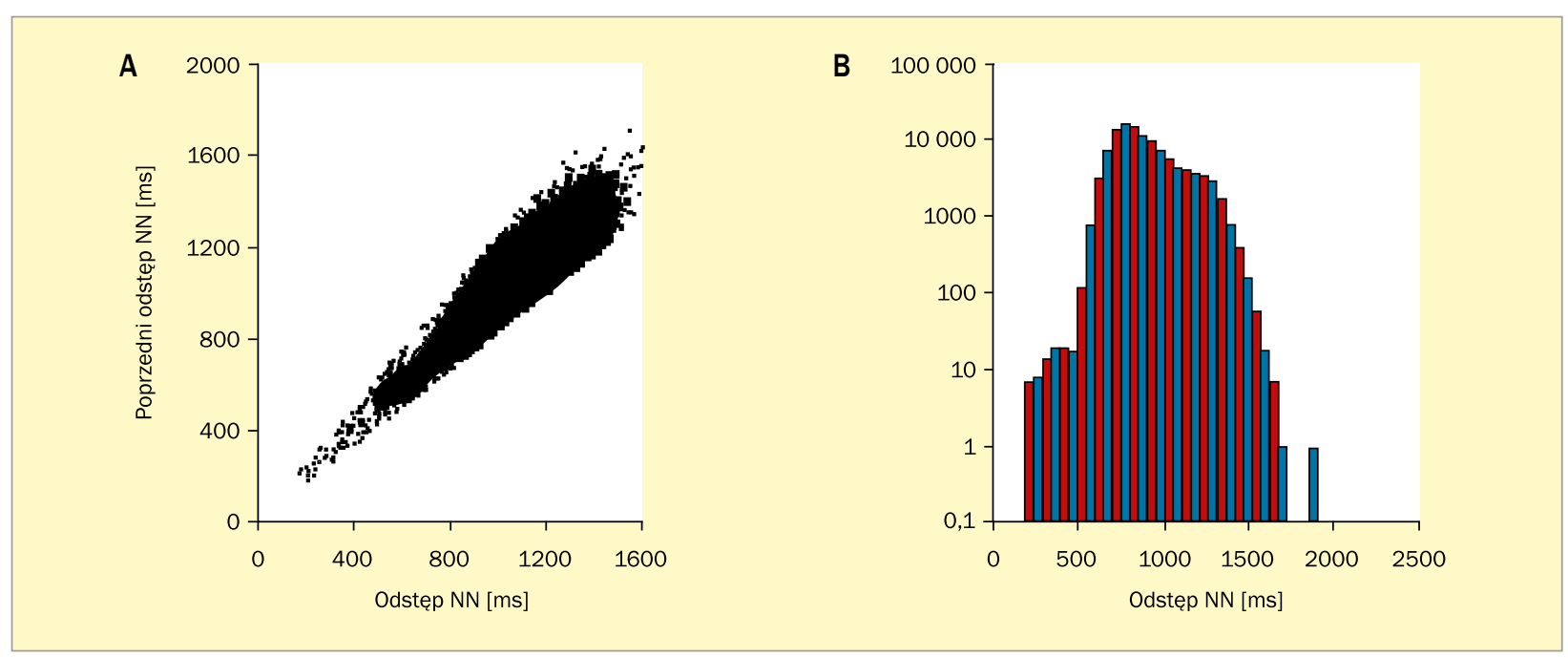

Rycina 2A, B. Rozkład Lorenza (A) i histogram (B) u zdrowej, 40-letniej kobiety (SDNN $182 \pm 52$ ms); materiał własny

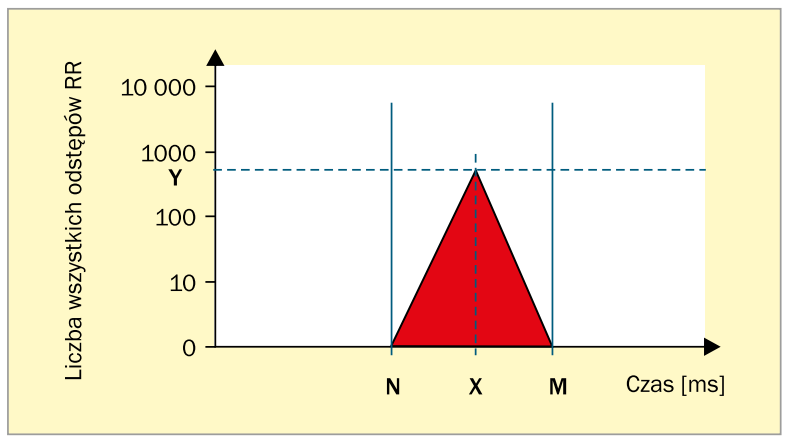

Rycina 3. Histogram odstępów NN i sposób obliczenia TINN (TINN $=\mathrm{M}-\mathrm{N}$ ); oś $\mathrm{Y}$ - całkowita liczba odstępów NN; oś $\mathrm{X}$ - czasy trwania odstępów NN; indeks trójkątny HRV $\left(\mathrm{HRV}_{\mathrm{i}}\right.$, heart rate variability triangular index) - liczba odstępów NN/Y (zmodyfikowano na podstawie [11], rys. poglądowy)

wą jest założenie, że rytm zatokowy to wypadkowa czynnika losowego, tworzącego szum pomiarowy i sumy składowych harmonicznych o różnej częstotliwości oscylacji. Wpływ poszczególnych składowych widma na częstość pracy serca określa się w takich jednostkach, jak amplituda widma (wyrażana w [ms]), moc widma (wyrażana w $\left[\mathrm{ms}^{2}\right]$ ) oraz gęstość mocy widma (wyrażana w $\left[\mathrm{ms}^{2} / \mathrm{Hz}\right]$ ) [14]. Istotą analizy jest utworzenie tachogramu - graficznej prezentacji wartości odstępów RR jako zmiennych w czasie (ryc. 4).
Do ostatecznego etapu analizy częstotliwościowej HRV wykorzystuje się metody nieparametryczne, związane ze stosowaniem szybkiej transformaty Fouriera - w dużym stopniu zależnej od długości analizowanego sygnału oraz metod parametrycznych - opartych na autoregresji. W analizie częstotliwościowej przedmiotem oceny jest zarówno całkowita moc widma (TP, total power), jak i jego składowe znajdujące się w zdefiniowanych przedziałach częstotliwościowych [15] (tab. 2). Dynamikę zmian HRV przedstawia się w postaci wykresu zmian średniej ruchomej badanego parametru w kolejnych przedziałach czasowych (ryc. 5).

Głównym problemem jest fakt, że wiarygodna interpretacja parametrów częstotliwościowych wymaga długiej rejestracji w warunkach bliskich stacjonarnym, co w praktyce jest trudne do osiągnięcia. Dodatkowo widma spektralne podlegają rytmom okołodobowym oraz między innymi wpływowi zmian aktywności układu renina-angiotensynaaldosteron i zmian napięcia mięśniówki gładkiej naczyń [16]. Całkowita moc widma określa sumaryczny wpływ składowych harmonicznych na rytm zatokowy i daje całościowe wyobrażenie o badanej zmienności rytmu. Można powiedzieć, że TP odzwierciedla aktywność całego układu autonomicznego i stanowi odpowiednik SDNN w analizie czasowej. Z kolei stosunek mocy gęstości widma niskich (LF, low frequency) do wysokich (HF, high frequency) częstotliwości (iloraz LF/HF) jest uznanym wskaźnikiem czynnościowej równowagi współczulno-przywspółczulnej,

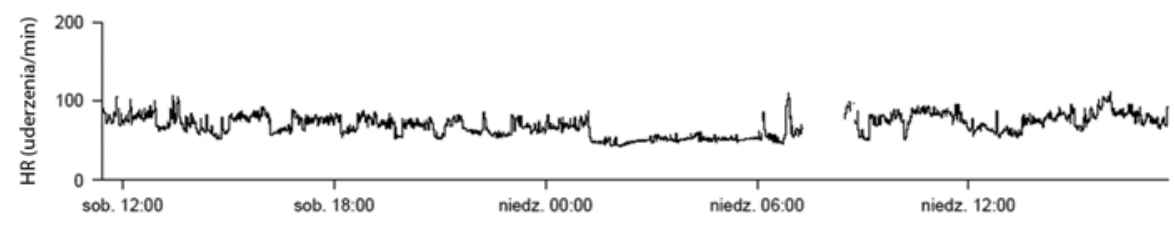

Rycina 4. Tachogram u zdrowej, 40-letniej kobiety (SDNN $182 \pm 52$ ms); HR (heart rate) - częstość pracy serca (materiał własny) 


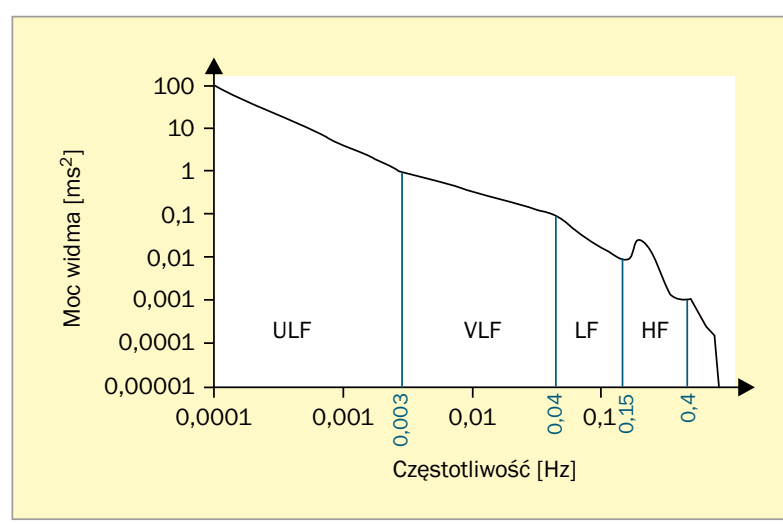

Rycina 5. Sposób wyznaczenia poszczególnych parametrów częstotliwościowych; ULF (ultra low frequency) - widmo ultraniskiej częstotliwości; VLF (very low frequency) - widmo bardzo niskiej częstotliwości; LF (low frequency) - widmo niskich częstotliwości; HF (high frequency) - widmo wysokich częstotliwości (zmodyfikowano na podstawie [15], rys. poglądowy)

Tabela 2. Poszczególne parametry częstotliwościowe (opracowanie własne na podstawie [15])

\begin{tabular}{|c|c|c|c|c|}
\hline \multicolumn{5}{|c|}{ Analiza spektralna } \\
\hline $\begin{array}{l}\text { Przedziały } \\
\text { częstotliwości }\end{array}$ & $\mathrm{HF}$ & LF & VLF & ULF \\
\hline $\begin{array}{l}\text { Częstotliwość } \\
\text { widma }[\mathrm{Hz}]\end{array}$ & $0,15-0,4$ & $0,04-0,15$ & $0,04-0,0033$ & $<0,0033$ \\
\hline $\begin{array}{l}\text { F (high frequency) - wi } \\
\text { ego i najczéściej korelu } \\
\text { ezstottiwości (obrazujac } \\
\text { opniu korelujacce z akty } \\
\text { ardzo niskiej czestotliw } \\
\text { enina-angiotensyna-al }\end{array}$ & $\begin{array}{l}\text { e aktywność kon } \\
\text { wnościa barorec } \\
\text { ości (świadczące } \\
\text { dosteron); ULF ( }\end{array}$ & $\begin{array}{l}\text { mponent współzzulr } \\
\text { eptorów tetniczych } \\
\text { o aktywności chem } \\
\text { ultra low frequency) }\end{array}$ & $\begin{array}{l}\text { zzujace działanie układu } \\
\text { LF (low frequency) - wi } \\
\text { Innej i przywspółczulnej, } \\
\text { :h); VLF (very low freque } \\
\text { moreceptorów i aktywn } \\
\text { y) - widmo ultraniskiej }\end{array}$ & $\begin{array}{l}\text { du przywspótzzul- } \\
\text { widmo niskich } \\
\text { j, w pewnym } \\
\text { ency) - widmo } \\
\text { ności układu } \\
\text { j czestotliwości }\end{array}$ \\
\hline
\end{tabular}

choć należy pamiętać, że na jego wartość wpływają rytmika oddychania i chwilowa częstość rytmu serca [17]. Aby podsumować oba przedstawione typy analizy HRV w domenie czasu i częstotliwości, w tabeli 3 zamieszczono przybliżone korelacje między poszczególnymi zmiennymi.

Poza analizami czasową i częstotliwościową spotyka się jeszcze analizę falkową, która łączy dziedziny czasu i częstotliwości. Jednak w praktyce jest rzadko stosowana, ponieważ wymaga ustalenia modelu obliczeniowego w sposób empiryczny [18]. Dodatkowo, ze względu na złożoność opisu rytmu serca, stosuje się metody dynamiki nieliniowej (wykresy Poincaré oraz tzw. wskaźniki entropii) [19].

\section{Interpretacja kliniczna HRV}

$\mathrm{U}$ zdrowych osób istnieje fizjologiczna HRV, a minimalną częstość pracy serca obserwuje się zwykle w czasie snu [9]. W przebiegu starzenia dochodzi do charakterystycznych zmian profilu HRV. Systematyczne obniżanie wskaźnika LF/ HF z wiekiem świadczy o wzrastającej roli napędu współczulnego w kontroli częstości pracy serca [20], a aktywność
Tabela 3. Przybliżone korelacje między zmiennymi analizy czasowej i częstotliwościowej (zmodyfikowano na podstawie [7])

$\begin{array}{lc}\text { Zmienna analizy czasowej } & \begin{array}{c}\text { Przybliżona korelacja ze zmienną } \\ \text { analizy częstotliwościowej }\end{array} \\ \text { SDNN } & \text { TP } \\ \text { HRV }_{i} & \text { TP } \\ \text { TINN } & \text { TP } \\ \text { SDANN } & \text { ULF } \\ \text { rMSSD } & \text { HF } \\ \text { pNN50 } & \text { HF }\end{array}$

TP (total power) - całkowita moc widma; $\mathrm{HRV}_{\mathrm{i}}$ (heart rate variability triangular index) - wskaźnik trójkątny zmienności rytmu serca; TINN (triangular interpolation of NN interval histogram) - interpolacja trójkątna histogramu odstępów NN; ULF (ultra low frequency) - widmo ultraniskiej częstotliwości; HF (high frequency) - widmo wysokich częstotliwości

przywspółczulna osiąga minimum w 8. dekadzie życia [21]. Utrzymanie aktywności przywspółczulnej na wysokim poziomie, promowane przez aktywność fizyczną, wpływa na dłuższe przeżycie i lepszą jakość życia [22]. Już w latach 90. XX wieku obserwowano wyższe ryzyko zgonu w przypadku niższych wskaźników HRV u osób w podeszłym wieku, a najlepszymi predyktorami okazały się parametry SDNN i LF [23]. W niektórych badaniach obserwowano tendencję do występowania niższych wartości wskaźnika LF/HF oraz niższych wartości LF i wyższych wartości HF u kobiet [24].

Większa HRV jest wyrazem dużych zdolności adaptacyjnych organizmu i koreluje z lepszym stanem zdrowia. Pierwsze badania w latach 70 . ubiegłego wieku wskazywały na związek obniżonej HRV z gorszym rokowaniem u chorych z pozawałową dysfunkcją lewej komory [25]. Obserwowano silny związek między redukcją HRV a wzrostem śmiertelności w pierwszych 3 latach od wystapienia zawału serca [26]. Dodatkowo obniżenie lub brak HRV niezależnie wskazuje na zagrożenie wystąpieniem arytmii komorowej [27]. Redukcję HRV obserwuje się w przebiegu choroby niedokrwiennej serca oraz u chorych po zabiegach kardiochirurgicznych $[28,29]$. Kilka przykładów analizy HRV w opracowaniu własnym autorów przedstawiono na rycinach 6 i 7 . W tabeli 4 zamieszczono przegląd wybranych jednostek i stanów chorobowych, uwzględniając ich potencjalny wpływ na HRV.

\section{Podsumowanie}

Niższe wartości HRV wiążą się z mniejszą równowagą w funkcjonowaniu autonomicznego układu nerwowego i stanowią czynnik ryzyka wystąpienia choroby. Parametr HRV ma tę niewątpliwą wartość, że jego zmiany mogą poprzedzać wystąpienie objawów klinicznych. Dlatego zastosowanie analizy HRV jako narzędzia w badaniu przesiewowym oraz stratyfikacji ryzyka zgonu z przyczyn sercowo-naczyniowych pozostaje zagadnieniem wartym uwagi. 

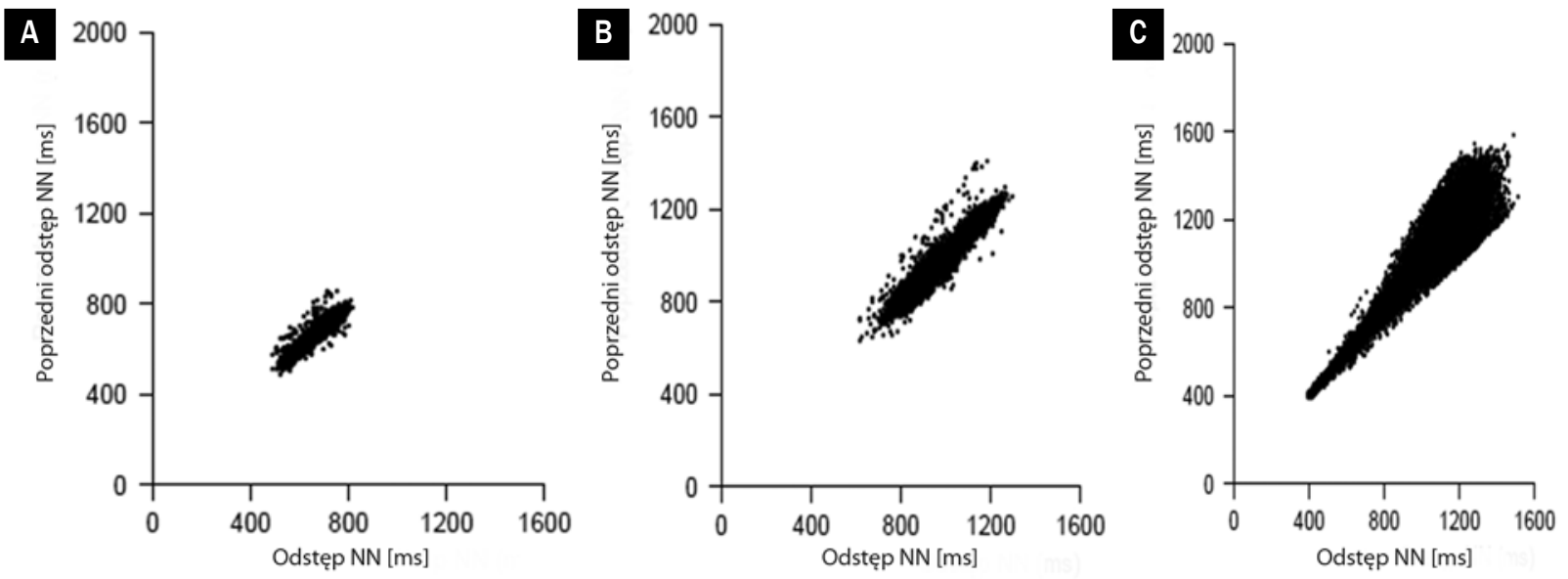

Rycina 6A-C. Przykładowe rozkłady Lorenza: A. Mężczyzna w wieku 55 lat z pozawałową niewydolnością serca, z frakcją wyrzutową lewej komory 35\% (SDNN $49 \pm 13$ ms); B. Mężczyzna w wieku 77 lat z cukrzycą typu 2 (SDNN $103 \pm 17$ ms); C. Kobieta w wieku 23 lat (SDNN $231 \pm 48 \mathrm{~ms}$ ); materiał własny

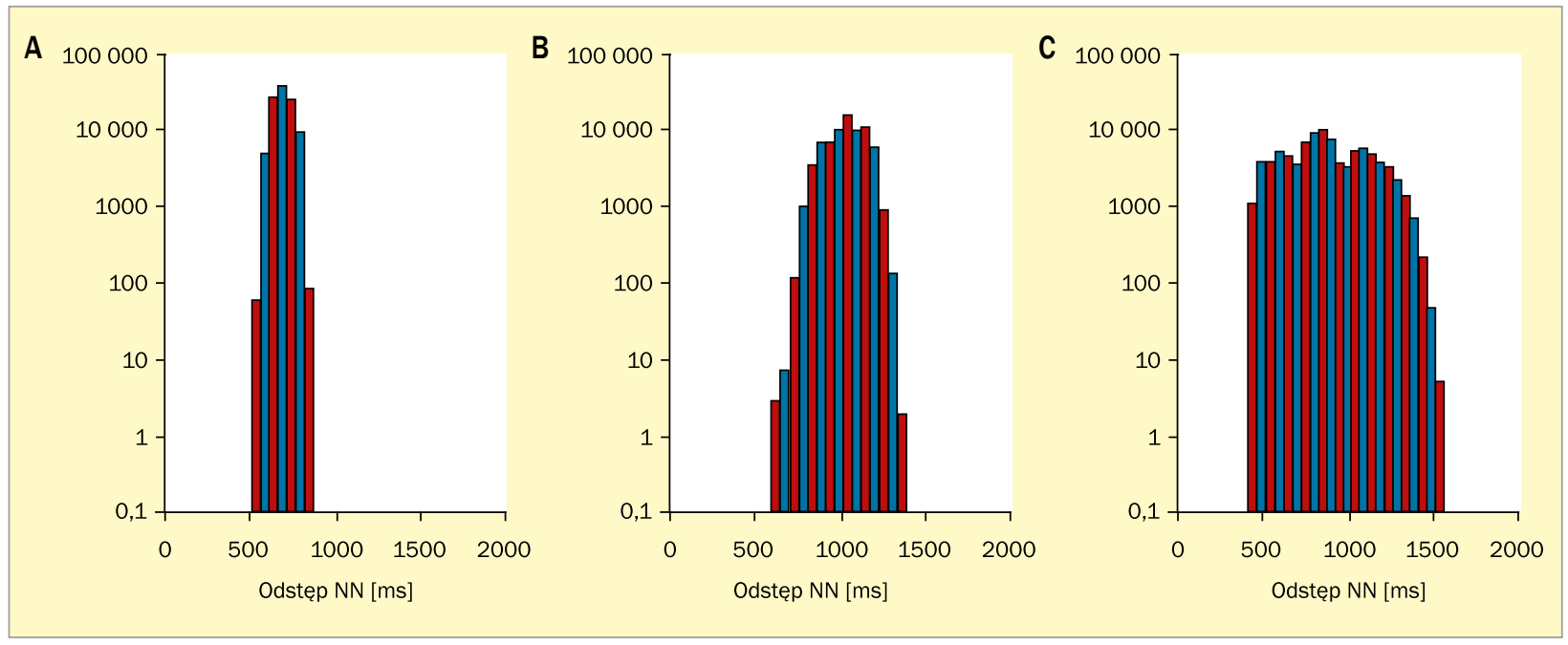

Rycina 7A-C. Przykładowe histogramy: A. Mężczyzna w wieku 55 lat z pozawałową niewydolnością serca, z frakcją wyrzutową lewej komory 35\% (SDNN $49 \pm 13$ ms); B. Mężczyzna w wieku 77 lat z cukrzycą typu 2 (SDNN $103 \pm 17 \mathrm{~ms}$ ); C. Kobieta w wieku 23 lat (SDNN $231 \pm 48$ $\mathrm{ms}) ;$ materiał własny

Prostota i nieinwazyjność tej metody zdają się zapewniać jej stałe miejsce na polu diagnostyki kardiologicznej, a ciągle dokonujący się postęp w zakresie metod statystycznych i systemów do oceny holterowskiej sprzyja udoskonalaniu istniejących oraz poszukiwaniu nowych modeli rozwiązań w tej dziedzinie.

\section{Abstract}

Heart rate variability estimates oscillations in intervals between heart beats represented by variable RR intervals on ECG record. Reduced heart rate variability is considered a non-invasive marker of autonomic dysfunction, which can predict a wide range of cardiovascular diseases leading to sudden cardiac death.

Key words: heart rate variability, Holter ECG, death predicting marker

Folia Cardiologica 2017; 12, 6: 617-624 
Tabela 4. Przegląd wybranych jednostek i stanów chorobowych z uwzględnieniem ich potencjalnego wpływu na zmienność rytmu serca (HRV, heart rate variability) (opracowanie własne na podstawie [2, 30-48])

\begin{tabular}{|c|c|c|c|}
\hline Stan/jednostka chorobowa & Specyfika zmian HRV & $\begin{array}{l}\text { Wyniki } \\
\text { (SDNN) }\end{array}$ & Autorzy, piśm. \\
\hline \multirow{2}{*}{$\begin{array}{l}\text { Serce przeszczepione (odner- } \\
\text { wione) }\end{array}$} & Zredukowana & & Bernardi i wsp., [30] \\
\hline & Rozpad współzależności w regulacji odstępów NN & & \\
\hline \multirow[t]{3}{*}{ Choroba wieńcowa } & Zredukowana & & Evrengul i wsp., [31] \\
\hline & Obniżony HF & & \\
\hline & Podwyższone LF i LF/HF & & \\
\hline \multirow[t]{4}{*}{ Po zawale serca } & Zredukowana & & La Rovere i wsp., [2] \\
\hline & SDNN < 70 ms - wyższa śmiertelność & & \\
\hline & $\begin{array}{l}\text { VLF - najsilniejszy predyktor śmiertelności i arytmii } \\
\text { komorowych }\end{array}$ & & Bigger i wsp., [32] \\
\hline & $\begin{array}{l}\text { Obniżony LF/HF w okresie okołozawałowym - istotny } \\
\text { predyktor śmiertelności 30-dniowej i rocznej }\end{array}$ & & Singh i wsp., [33] \\
\hline \multirow[t]{5}{*}{ Niewydolność serca } & Zredukowana & Obniżone SDNN, & Nolan i wsp., [34] \\
\hline & $\begin{array}{l}\text { (III-IV klasa wg NYHA v. II klasa wg NYHA, korelacja } \\
\text { z EF) }\end{array}$ & SDANN & $\begin{array}{l}\text { Musialik-Łydka i wsp., } \\
\text { [35] }\end{array}$ \\
\hline & $\mathrm{LF}<13 \mathrm{~ms}^{2}-$ predyktor SCD w NS & & La Rovere i wsp., [36] \\
\hline & Obniżony HF & & Binkley i wsp., [37] \\
\hline & Podwyższony LF/HF & & \\
\hline $\begin{array}{l}\text { Arytmie komorowe u chorych } \\
\text { z NS (nsVT, sVT) }\end{array}$ & Zredukowana & $\begin{array}{l}\text { Obniżone SDNN, } \\
\text { SDANN }\end{array}$ & $\begin{array}{l}\text { Musialik-Łydka i wsp., } \\
\text { [35] }\end{array}$ \\
\hline \multirow[t]{2}{*}{ Kardiomiopatia rozstrzeniowa } & Zredukowana & $39 \pm 23 \mathrm{~ms}$ & Vester i wsp., [38] \\
\hline & Obniżony LF & & Biswas i wsp., [39] \\
\hline \multirow[t]{2}{*}{ Idiopatyczna DCM } & Zredukowana (korelacja z EF, LVDD, NYHA) & & Yi i wsp., [40] \\
\hline & SDNN $<50$ ms prognozował progres NS & & \\
\hline \multirow[t]{2}{*}{ Zapalenie mięśnia sercowego } & Zredukowana & $44 \pm 16 \mathrm{~ms}$ & Vester i wsp., [38] \\
\hline & (normalizacja po 6 mies.) & & Gao i wsp., [41] \\
\hline \multirow[t]{3}{*}{ Kardiomiopatia przerostowa } & Zredukowana & $45 \pm 28 \mathrm{~ms}$ & Vester i wsp., [38] \\
\hline & Obniżone pNN50, HF & & Counihan i wsp., [42] \\
\hline & LF/HF $<1,2$ - wysokie ryzyko SCD u dzieci & & Butera i wsp., [43] \\
\hline $\begin{array}{l}\text { Ciężka wada aortalna (AS, AR, } \\
\text { złożona AS/AR) }\end{array}$ & $\begin{array}{l}\text { Zredukowana (niezależnie od EF, gradientu przezaor- } \\
\text { talnego) }\end{array}$ & $96,8 \pm 30,9 \mathrm{~ms}$ & Jung i wsp., [44] \\
\hline $\begin{array}{l}\text { Po niepowikłanym AVR } \\
\text { (1 tydz. od procedury) }\end{array}$ & Zredukowana & $61,5 \pm 23,5 \mathrm{~ms}$ & Jung i wsp., [44] \\
\hline \multirow{3}{*}{$\begin{array}{l}\text { Wypadanie płatka zastawki } \\
\text { mitralnej }\end{array}$} & Niezmieniona & & Gunduz i wsp., [45] \\
\hline & Obniżony HF & & Marangoni i wsp., [46] \\
\hline & Wyższy LF/HF u dzieci & & Han i wsp., [47] \\
\hline $\begin{array}{l}\text { Przewlekła niedomykalność } \\
\text { mitralna }\end{array}$ & $\begin{array}{l}\text { SDANN - korelował z funkcją LV i RV, predyktor pro- } \\
\text { gresu do operacji, wczesnej śmiertelności, rozwoju AF }\end{array}$ & & Stein i wsp., [48] \\
\hline
\end{tabular}




\section{Piśmiennictwo}

1. http://ec.europa.eu/eurostat/statistics-explained/index.php/Causes_of_death_statistics/pl.

2. LA Rovere M, Bigger J T, Marcus F, et al. Baroreflex sensitivity and heart-rate variability in prediction of total cardiac mortality after myocardial infarction. Lancet. 1998; 351(9101): 478-484, doi: 10.1016/ s0140-6736(97)11144-8, indexed in Pubmed: 9482439.

3. Hon EH, Lee ST. Electronic evaluation of the fetal heart rate. VIII. Patterns preceding fetal death, further observations. Am J Obstet Gynecol. 1963; 87: 814-826, indexed in Pubmed: 14085784.

4. Stauss HM. Heart rate variability. Am J Physiol Regul Integr Comp Physiol. 2003; 285(5): R927-R931, doi: 10.1152/ajpregu.00452.2003, indexed in Pubmed: 14557228.

5. Cygankiewicz I, Zareba W. Heart rate variability. Handb Clin Neurol. 2013; 117: 379-393, doi: 10.1016/B978-0-444-53491-0.00031-6, indexed in Pubmed: 24095141.

6. Task Force of the European Society of Cardiology and the North American Society of Pacing and Electrophysiology. Heart rate variability: standards of measurement, physiological interpretation, and clinical use. Circulation. 1996; 93(5): 1043-1065, doi: 10.1161/01. cir.93.5.1043, indexed in Pubmed: 8598068.

7. Ernst G. Heart rate variability. Springer, London 2014.

8. Pawlak-Buś K, Kołodziejczyk-Feliksik M, Czerwiński-Mazur P, et al. Zmienność rytmu zatokowego - interpretacja patofizjologiczna i metodologia pomiarów. Folia Cardiol. 2003; 10: 719-726.

9. Malik M, Camm A. Components of heart rate variability - what they really mean and what we really measure. Am J Cardiol. 1993; 72(11): 821-822, doi: 10.1016/0002-9149(93)91070-x, indexed in Pubmed: 8093124.

10. Moczko J, Kramer L. Cyfrowe metody przetwarzania sygnałów biomedycznych. Wydawnictwo Naukowe UAM, Poznań 2001.

11. Krauze T, Guzik P, Wysocki H. Zmienność rytmu serca: aspekty techniczne. Now Lek. 2001; 70(9): 973-984.

12. Bailey JJ, Berson AS, Garson A, et al. Recommendation for standardization and specifications in automated electrocardiography. Circulation. 1990; 81(2): 730-739, indexed in Pubmed: 2297875.

13. Akselrod S, Gordon D, Ubel F, et al. Power spectrum analysis of heart rate fluctuation: a quantitative probe of beat-to-beat cardiovascular control. Science. 1981; 213(4504): 220-222, doi: 10.1126/ science.6166045, indexed in Pubmed: 6166045.

14. Piotrowicz R. Zmienność rytmu serca. Via Medica, Gdańsk 1995.

15. Pięciak T. Analiza zmienności rytmu(HRV). http://home.agh.edu.pl/ pieciak. (14.11.2017).

16. Milicević G. Low to high frequency ratio of heart rate variability spectra fails to describe sympatho-vagal balance in cardiac patients. Coll Antropol. 2005; 29: 295-300, indexed in Pubmed: 16117339.

17. Billman $\mathrm{G}$. The effect of heart rate on the heart rate variability response to autonomic interventions. Front Physiol. 2013; 4(222): 1-9, doi: 10.3389/fphys.2013.00222, indexed in Pubmed: 23986716.

18. Juvet T, Abdelhadi S. Studium porównawcze nad wpływem tlenowej terapii hiperbarycznej na zmienność rytmu zatokowego przy wykorzystaniu analizy fali elementarnej i szybkiej transformaty Fouriera. Polish Hyperb Res. 2013; 4(45): 19-36, doi: 10.13006/phr.45.2.

19. Sassi R, Cerutti S, Lombardi F, et al. Advances in heart rate variability signal analysis: joint position statement by the e-Cardiology ESC Working Group and the European Heart Rhythm Association co-endorsed by the Asia Pacific Heart Rhythm Society. Europace. 2015; 17(9): 1341-1353, doi: 10.1093/europace/euv015, indexed in Pubmed: 26177817.
20. Abhishekh HA, Nisarga P, Kisan R, et al. Influence of age and gender on autonomic regulation of heart. J Clin Monit Comput. 2013; 27(3): 259-264, doi: 10.1007/s10877-012-9424-3, indexed in Pubmed: 23297094.

21. Zulfiqar U, Jurivich DA, Gao W, et al. Relation of high heart rate variability to healthy longevity. Am J Cardiol. 2010; 105(8): 1181-1185, doi: 10.1016/j.amjcard.2009.12.022, indexed in Pubmed: 20381674.

22. Elias MF, Goodell AL, Dore GA. Hypertension and cognitive functioning: a perspective in historical context. Hypertension. 2012; 60(2): 260-268, doi: 10.1161/HYPERTENSIONAHA.111.186429, indexed in Pubmed: 22753214.

23. Tsuji $H$, Venditti FJ, Manders ES, et al. Reduced heart rate variability and mortality risk in an elderly cohort. The Framingham Heart Study. Circulation. 1994; 90(2): 878-883, doi: 10.1161/01.cir.90.2.878, indexed in Pubmed: 8044959.

24. Huikuri HV, Pikkujamsa SM, Airaksinen K, et al. Sex-related differences in autonomic modulation of heart rate in middle-aged subjects. Circulation. 1996; 94(2): 122-125, doi: 10.1161/01.cir.94.2.122, indexed in Pubmed: 8674168.

25. Wolf MM, Varigos GA, Hunt D, et al. Sinus arrhythmia in acute myocardial infarction. Med J Aust. 1978; 2(2): 52-53, indexed in Pubmed: 713911.

26. Kleiger RE, Miller JP, Bigger JT, et al. Decreased heart rate variability and its association with increased mortality after acute myocardial infarction. Am J Cardiol. 1987; 59(4): 256-262, doi: 10.1016/00029149(87)90795-8, indexed in Pubmed: 3812275.

27. Algra A, Tijssen JG, Roelandt JR, et al. Heart rate variability from 24-hour electrocardiography and the 2-year risk for sudden death. Circulation. 1993; 88(1): 180-185, doi: 10.1161/01.cir.88.1.180, indexed in Pubmed: 8319331.

28. Wachowiak-Baszyńska H, Ochotny R. Zmienność rytmu zatokowego w chorobie niedokrwiennej serca. Folia Cardiol. 2001; 8: 109-117.

29. Bryniarski L, Kawwa J, Rajzer M, et al. Heart rate variability in patients after coronary artery bypass grafting-early and long term effects of cardiac rehabilitation. Przegl Lek. 2002; 59(9): 699-702, indexed in Pubmed: 12632889.

30. Bernardi L, Salvucci F, Suardi R, et al. Evidence for an intrinsic mechanism regulating heart rate variability in the transplanted and the intact heart during submaximal dynamic exercise? Cardiovasc Res. 1990; 24(12): 969-981, indexed in Pubmed: 2097063.

31. Evrengul $\mathrm{H}$, Tanriverdi $\mathrm{H}$, Kose $\mathrm{S}$, et al. The relationship between heart rate recovery and heart rate variability in coronary artery disease. Ann Noninvasive Electrocardiol. 2006; 11(2): 154162, doi: 10.1111/j.1542-474X.2006.00097.x, indexed in Pubmed: 16630090.

32. Bigger JT, Fleiss JL, Steinman RC, et al. Frequency domain measures of heart period variability and mortality after myocardial infarction. Circulation. 1992; 85(1): 164-171, doi: 10.1161/01.cir.85.1.164, indexed in Pubmed: 1728446.

33. Singh N, Mironov D, Armstrong PW, et al. Heart rate variability assessment early after acute myocardial infarction: pathophysiological and prognostic correlates. Circulation. 1996; 93(7): 1388-1395, doi: 10.1161/01.cir.93.7.1388, indexed in Pubmed: 8641028.

34. Nolan J, Batin PD, Andrews R, et al. Prospective study of heart rate variability and mortality in chronic heart failure: results of the United Kingdom Heart Failure Evaluation and Assessment of Risk Trial (UK-Heart). Circulation. 1998; 98(15): 1510-1516, doi: 10.1161/01. cir.98.15.1510, indexed in Pubmed: 9769304. 
35. Musialik-Łydka A, Sredniawa B, Pasyk S. Heart rate variability in heart failure. Kardiol Pol. 2003; 58(1): 10-16, indexed in Pubmed: 14502297.

36. La Rovere MT, Pinna GD, Maestri R, et al. Short-term heart rate variability strongly predicts sudden cardiac death in chronic heart failure patients. Circulation. 2003; 107(4): 565-570, doi: 10.1161/01. cir.0000047275.25795.17, indexed in Pubmed: 12566367.

37. Binkley P, Nunziata E, Haas G, et al. Parasympathetic withdrawal is an integral component of autonomic imbalance in congestive heart failure: demonstration in human subjects and verification in a paced canine model of ventricular failure. J Am Coll Cardiol. 1991; 18(2): 464-472, doi: 10.1016/0735-1097(91)90602-6, indexed in Pubmed: 1856414.

38. Vester EG, Emschermann C, Stobbe U, et al. Late potentials and heart rate variability in heart muscle disease. Eur Heart J. 1994; 15(Suppl C): 25-33, doi: 10.1093/eurheartj/15.suppl_c.25, indexed in Pubmed: 7995267.

39. Biswas PK, Basu S, Mitra KK, et al. Heart rate variability in dilated cardiomyopathy. Indian Heart J. 2000; 52(2): 187-191, indexed in Pubmed: 10893896.

40. Yi G, Goldman JH, Keeling PJ, et al. Heart rate variability in idiopathic dilated cardiomyopathy: relation to disease severity and prognosis. Heart. 1997; 77(2): 108-114, doi: 10.1136/hrt.77.2.108, indexed in Pubmed: 9068391.

41. Gao X, Peng L, Zeng Q, et al. Autonomic nervous function and arrhythmias in patients with acute viral myocarditis during a 6-month follow-up period. Cardiology. 2009; 113(1): 66-71, doi: 10.1159/000167794, indexed in Pubmed: 18987467.

42. Counihan PJ, Fei L, Bashir Y, et al. Assessment of heart rate variability in hypertrophic cardiomyopathy. Association with clinical and prognostic features. Circulation. 1993; 88(4 Pt 1): 1682-1690, doi: 10.1161/01.cir.88.4.1682, indexed in Pubmed: 8403313.

43. Butera G. Heart rate variability in children with hypertrophic cardiomyopathy. Heart. 2003; 89(2): 205-206, doi: 10.1136/heart.89.2.205, indexed in Pubmed: 12527679.

44. Jung J, Heisel A, Tscholl D, et al. Factors influencing heart rate variability in patients with severe aortic valve disease. Clin Cardiol. 1997; 20(4): $341-$ -344, doi: 10.1002/clc.4960200408, indexed in Pubmed: 9098592.

45. Gunduz H, Arinc $\mathrm{H}$, Kayardi M, et al. Heart rate turbulence and heart rate variability in patients with mitral valve prolapse. Europace. 2006; 8(7): 515-520, doi: 10.1093/europace/eul059, indexed in Pubmed: 16798765.

46. Marangoni S, Scalvini S, Mai R, et al. Heart rate variabilityassessment in patients withmitral valve prolapse syndrome. Am J Noninvas Cardiol. 1993; 7(4): 210-214, doi: 10.1159/000470281.

47. Han L, Ho TF, Yip WC, et al. Heart rate variability of children with mitral valve prolapse. J Electrocardiol. 2000; 33(3): 219-224, doi: 10.1054/ jelc.2000.7661, indexed in Pubmed: 10954374.

48. Stein KM, Borer JS, Hochreiter C, et al. Prognostic value and physiological correlates of heart rate variability in chronic severe mitral regurgitation. Circulation. 1993; 88(1): 127-135, doi: 10.1161/01. cir.88.1.127, indexed in Pubmed: 8319325. 